DOI https://doi.org/10.30525/978-9934-26-073-5-1-56

\title{
ЛІНГВОКУЛЬТУРНІ АСПЕКТИ СВІТУ КОМІЧНОГО У НІМЕЦЬКІЙ МОВІ
}

\author{
Зубач О. А. \\ кандидат філологічних наук, \\ доиент кафедри німецької філології \\ Волинського наиіонального університету імені Лесі Украӥнки \\ м. Луиькк, Украӥна
}

У світі німецького гумору відображаються ціннісні орієнтири сміхової культури носіїв мови та специфічні константи людської когніції. Сприйняття гумору у культурах різних народів $\epsilon$ національно-специфічним та не завжди зрозумілим для інших лінгвокультур. Лінгвокультурна особливість світу комічного фіксується крізь призму взаємодії інтра- та екстралінгвальних чинників, що відображається на формуванні поведінкових стереотипів та стратегій та тактик комунікативного акту мовної особистості у міжкультурній комунікації.

Лінгвальне вираження гумору простежується у семантичних, структурно-семантичних та стилістичних, зокрема у емоційно-експресивних модифікаціях. Екстралінгвальні ознаки прагматизуються у словесноситуативних засобах формування комічного ефекту. Етноспецифічні ознаки комічного в німецькій лінгвокультурі спостерігаються у жанрі шванку, який вважають своєрідною ланкою формування комічного світу у німецькій лінгвокультурі.

Актуальність дослідження полягає у вивчення лінгвокультурної особливості світу комічного та його прагматизації у німецькому лінгвокультурному просторі. Суть діалектики світу комічного у науковій парадигмі знань викликає великий інтерес, оскільки комічне розуміють як єдину естетичну форму смішного [2; 3] або як прояв душевного стану людини [1].

Світ комічного у німецькій лінгвокультурі $є$ свідченням того, що людина здатна забарвлювати негативні явища та негаразди позитивною конотацією використовуючи культуру тіла через жести або міміку, а саме вираження настрою та почуттів, та $\epsilon$ результатом відображення стереотипного уявлення про правила комунікативної поведінки німців, австрійців та швейцарців.

Гумор досліджується 3 різних фокусів наукової парадигми. У комунікативній лінгвістиці гумор розглядається як конструкт для 
послаблення конфліктної ситуації або зменшення рівня напруги з метою експлікації ціннісних орієнтирів комунікації. У когнітивній лінгвістиці гумор сприймається як світ культурно-зумовлених стереотипів та квант внутрішнього світу німецької лінгвокультури та експліцитного розуміння та сприйняття реального світу. У прагмалінгвістиці комічне $\epsilon$ національно-специфічним ідентифікатором лінгвокультурного світу та інструментом для здійснення комунікативних актів 3 метою збереження національно-культурного компонента у німецьких жартах, табуйованих жартах та жартах-оригіналу з інших культур. У психолінгвістиці гумор вербалізує перцептивно-інформаційний стан мовної особистості та відносини у моментах комунікативного акту.

Багатовимірність комічного явища, 3 одного боку, фіксує динамічність потенційної інтенції учасників комунікації виражати комічне та абсурдне через сатиру, іронію або жарт, напр., Scherz, Satire, Ironie und tiefere Bedeutung [4, с. 456], з іншого - актуалізує парадоксальність та ефект несподіваності сприйняття та репрезентації кодів культури носіїв мови. Суть його естетичної прагматики висвітлюється крізь механізми вербальної комунікації, де відбувається поєднання реального та життєвого, національно-специфічного та загальнонаціонального.

Гумор $\epsilon$ продуктом комічної культури або культури сміху та результатом логічних операцій та своєрідним виміром поняттєвої категорії комічного, що грунтується на фонових знаннях, які формуються внаслідок взаємодії суспільно-історичних процесів, природніх явищ, побутових ситуацій з метою збереження ідентичності мовної особистості лінгвокультурної спільноти. Ідентичність мовної особистості виражається крізь взаємодію механізмів осмислення фрагментів дійсності реального світу зі збереженням розважального ефекту.

В семантичній парадигмі гумору простежуються ознаки маніпулювання свідомістю та стимулювання до відповідної реакції та дій за рахунок дотримання мовних, мовленнєвих та поведінкових особистісних смислів, що впливає на формування специфічних характеристик мовленнєвого етикету, а саме вікових, гендерних, соціальних. Основними функціями гумору є розважальна, маскувальна та медіаційна. Драматичність конотативних рис особливо яскраво висвітлюється у «чорному» гуморі, який викликає агресію та негативну реакцію.

Комічний світ німецької мовної картини світу $\epsilon$ своєрідною траєкторією розвитку німецького суспільства в умовах глобалізації світу, а гумор є знаком емоційно-чуттєвого ментального утворення з розважальним ефектом, який експліцитно репрезентує коди культури, зокрема елементи матеріальної культури крізь ідентифікатори Humor, Scherz, 
Witz, Anekdote usw. План змісту гумору фіксується у контекстуальній оболонці діалогічної або монологічної форми представлення комічної ситуації. План вираження формується через знакову та асоціативну природу структури гумору у результаті процесів вербалізації.

Перспективним вбачаються питання щодо виявлення семантичних та структурних шляхів формування пріоритетних ідентифікаторів комічного у німецькій мові.

\title{
Література:
}

1. Пропп В. Я. Проблемы комизма и смеха. М. : Искусство, 1976. $182 \mathrm{c}$.

2. Lipps Th. Komik und Humor. Lpz., 1922. 67 S.

3. Raskin V. The Semantic Mechanisms of Humor. Reidel : Dordrecht, 1985. $280 \mathrm{p}$.

4. Duden 12. Zitate und Aussprüche. Dudenverlag : Mannheim. Leipzig. Wien. Zürich., 2002. 960 S.

DOI https://doi.org/10.30525/978-9934-26-073-5-1-57

\section{ВИВЧЕННЯ ІНОЗЕМНОЇ ПРОФЕСІЙНОЇ ЛЕКСИКИ У ВНЗ}

\author{
Іванова T. B. \\ викладач кафедри іноземних мов професійного спілкування \\ Міжнародного гуманітарного університету \\ м. Одеса, Украӥна
}

В останні роки вивчення англійської мови в вищих навчальних вузах набуває особливого значення. Світ вступив в епоху глобалізації тому йому потрібні фахівці, здатні плідно працювати в умовах глобалізації. Випускники вузів, які в подальшому будуть вирішувати важливі завдання соціально-економічного розвитку країни та модернізації економіки, повинні не тільки володіти знаннями $з$ фахової спеціальності та вивчення іiі дисциплін, а й володіти міжнародною мовою тобто англійською. Для того щоб випускник вузу міг читати літературу за фахом і спілкуватися зі своїми зарубіжними колегами на професійному рівні, йому необхідно добре знання не тільки загальновживаної, але i професійної лексики.

Лексика є важливим компонентом мовленнєвої діяльності. Від рівня володіння лексичною стороною мовленнєвої діяльності в значній мірі 